$10-2017$

\title{
Book Review: Marching into Darkness: The Wehrmacht and the Holocaust in Belarus
}

Lauren Faulkner Rossi

Simon Fraser University

Follow this and additional works at: https://digitalcommons.usf.edu/gsp

\section{Recommended Citation}

Rossi, Lauren Faulkner (2017) "Book Review: Marching into Darkness: The Wehrmacht and the Holocaust in Belarus," Genocide Studies and Prevention: An International Journal: Vol. 11: Iss. 2: 109-111.

DOI:

http://doi.org/10.5038/1911-9933.11.2.1475

Available at: https://digitalcommons.usf.edu/gsp/vol11/iss2/11

This Book Review is brought to you for free and open access by the Open Access Journals at Digital Commons @ University of South Florida. It has been accepted for inclusion in Genocide Studies and Prevention: An International Journal by an authorized editor of Digital Commons @ University of South Florida. For more information, please contact digitalcommons@usf.edu. 
Book Review: Marching into Darkness: The Wehrmacht and the Holocaust in Belarus

\author{
Lauren Faulkner Rossi \\ Simon Fraser University \\ Burnaby, British Columbia, Canada
}

Marching into Darkness: The Wehrmacht and the Holocaust in Belarus

Waitman Wade Beorn

Cambridge, Harvard University Press, 2014

314 Pages; Price: $\$ 42.00$ Hardcover

Reviewed by Lauren Faulkner Rossi

Simon Fraser University

In light of Bryan Cheyette's recent query in the Times Literary Supplement about "too much Holocaust," one might wonder if another book on Holocaust perpetrators adds anything new to a decades-old discussion. Christopher Browning's seminal study of Police Battalion 101 in Poland first appeared in 1992, only a year after Omer Bartov's equally important analysis of ideological indoctrination in the Wehrmacht. ${ }^{1}$ Since then, scholars in numerous fields and countries have devoted their careers to scrutinizing what motivates men (and sometimes women) to engage in genocide. Have we not exhausted all possible explanations, satisfactory or otherwise, for this? Waitman Beorn's answer to this question in Marching into Darkness is an unqualified no.

Beorn attempts to draw together numerous strands in Holocaust historiography and references both Browning and Bartov as important pioneers to reframe the debate about perpetrator motivation. In his own words, he insists that understanding these individuals "requires untangling the complex interplay of psychological pressures, belief systems, training, leadership, situational pressures, institutional memory, and organizational standards." ${ }^{2}$ This might seem like a messy description, but given the scope and scale of what Beorn is tackling, there is not likely to be a more satisfying simpler one. He insists that both the social-psychological dimensions underscored in Browning's argument as well as the indoctrination angle pursued by Bartov apply equally and simultaneously to soldiers who engaged in killing unarmed men, women, and children on the Eastern Front. The period and landscape of Beorn's study are important: he confines himself to Belarus from the late summer of 1941 through the winter of 1941/1942, after the Wehrmacht had begun its occupation but before its descent into the "death spiral" of killing that would later come to define this area. He also limits himself to specific groups within the Wehrmacht, namely, several companies in three infantry regiments that left records proving participation in the genocide of Jews.

Beorn offers a three-part argument about why these particular soldiers became killers: he delineates the importance of military unit leadership and culture in determining who participatedand who did not; he defines a "Jew-Bolshevik-partisan" calculus that the soldiers used to determine whether and to what extent they would participate in the killing as well as to justify that participation; and he affirms that repeated and prolonged exposure to genocide led to the soldiers' consistent and deeper involvement. He also provides broader context for Wehrmacht activities in identifying that the German military breached the border of the Soviet Union in June 1941 "with a set of baseline practices and default responses to dealing with civilians that already veered toward excess, ${ }^{3}$ referring to its experiences especially in Poland (which Beorn largely glosses over) but

\footnotetext{
"Bryan Cheyette, "Too much Holocaust?," Times Literary Supplement, last modified January 17, 2017, http://www.the-tls. co.uk/articles/public/too-much-holocaust/; Christopher R. Browning, Ordinary Men: Police Battalion 101 and the Final Solution in Poland (New York: HarperCollins, 1992); Omer Bartov, Hitler's Army: Soldiers, Nazis, and War in the Third Reich (Oxford: Oxford University Press, 1991).

${ }^{2}$ Waitman Wade Beorn, Marching into Darkness: The Wehrmacht and the Holocaust in Belarus (Cambridge: Harvard University Press, 2014), 20.

${ }^{3}$ Ibid., 41.
}

Lauren Faulkner Rossi, "Book Review: Marching into Darkness: The Wehrmacht and the Holocaust in Belarus" Genocide Studies and Prevention 11, 2 (2017): 109-111. @2017 Genocide Studies and Prevention. 
also in western, northern, and southeastern Europe. His chronological examination of the 354th Infantry Regiment's largely improvised mass murder of Jews in Krupki; the 3rd Company's planned execution of the Jews of Krucha, with whom they had lived for several months; the 727th Infantry Regiment's mass execution of Jews in the Czepilov Forest; and the "Jew hunts" perpetrated by volunteers from 12th Company (of the 727th Infantry Regiment) demonstrate a steady descent into violence and brutality and an increased willingness to participate in genocide. Beorn reveals that documentary evidence exists, but much has been lost, and he relies primarily on judicial proceedings of the handful who went to trial in the postwar period for information. The very few men who chose not to participate (and were not punished) were anomalies that should jar us into acknowledging that the majority chose to participate, for a variety of reasons. The reasons for doing so that appear most often in the sources, according to Beorn, were agreement with the lethal policy, deference to authority, and fear of the social consequences of refusing to do one's part.

For those readers familiar with the field of Holocaust studies, much of Beorn's book seems to retread old ground. He is not advancing an original interpretation of why men participated in genocide, but rather weaves together several older arguments. Nor is evidence of Wehrmacht participation in the genocide a revelation; this fact has been established in the historiography for decades, and in the public consciousness since the travelling Wehrmacht exhibit in Germany in the late 1990s. In his introduction he acknowledges some of the existing scholarship in this area but contends that many of these macro-histories, scrutinizing division-level or higher behaviour, cannot explain the "internal dynamics of killing units." 4 Microhistories, or studies focused on "those German soldiers on the frontiers of human cruelty," ${ }^{5}$ bring us closer to comprehending why men behaved as they did. What Beorn offers is a microhistory, with particular German infantry regiments operating in Belarus at its center. Thus readers will note that the book's most significant challenge is one shared by all such microhistories: it is the challenge of proving its broader relevance. To what extent are the actions of a few thousand men, at most, representative of the larger military behemoth of which they were part, in which some seventeen million men served over the course of the war? ${ }^{6}$ Beorn understands this and knows that, at most, he can speak definitively only about potentials. But it is difficult to disagree with his evidence, which demonstrates how anti-Jewish policy created at the highest levels of the Nazi regime was carried out daily by German footsoldiers during the Second World War.

Even if the broader argument may not advance significantly our understanding of why individuals commit genocide, Beorn offers much that is insightful and fresh within his particular context. His analysis that the Mogilev Conference, held in Belarus in early October 1941, was a crucial turning-point for Wehrmacht involvement in genocide, at least in that area, fills a gap in the narrative of the Holocaust, in which until very recently Belarus did not feature predominantly. He presents Mogilev on a par with Wannsee, but differentiates the two conferences in that the former set the pace for mass murder that was about to unfold, whereas Wannsee in January 1942 largely sanctioned what was already happening. Given the significance he assigns to the Mogilev Conference in terms of the army's complicity in genocide, it is curious that he does not mention Himmler's visit to that city at roughly the same time, when he oversaw the execution of 279 Jews at a slave labour camp, ${ }^{7}$ though he notes that Himmler met with Hitler shortly after this visit, in December $1941 .{ }^{8}$ Did the presence of the Reichsführer-SS factor at all into conference discussions and decisions? The setting of Belarus itself is a welcome addition to the historiography, and one of the book's chief strengths; what does exist is heavily focused on Jewish resistance and partisan activity, the Bielski brothers being the most famous. Beorn makes Belarus central as a theater of genocidal operations. As much as his sources permit, Beorn also includes the voices of some of

\footnotetext{
${ }^{4}$ Ibid., 16.

${ }^{5}$ Ibid., 25 .

${ }^{6}$ Rüdiger Overmanns, Deutsche militärische Verlust im Zweiten Weltkrieg (Berlin: De Gruyter Oldenbourg, 2004).

${ }^{7}$ Peter Longerich, Heinrich Himmler: A Life (Oxford: Oxford University Press, 2013), 538.

${ }^{8}$ Beorn, Marching into Darkness, 180.
} 
the Jewish survivors, which is a methodologically rare approach to analysis in a field that tends to focus exclusively on perpetrators. Consequently, his narrative of atrocities is less one-sided and more affecting. Finally, the inclusion of the stories of soldiers who not only refused to commit genocide (Josef Sibille) but actively helped to protect Jews they knew (Joachim Lochbihler) are both useful and necessary to emphasize how rare these individuals were, and how army participation in murder became very much the norm by the end of 1941 in Belarus.

As 1941 gave way to 1942, Beorn notes an intensification in voluntary brutality, as soldiers began to exhibit evident pleasure in tormenting and torturing their victims before killing them. Soldiers of at least one company volunteered to take part in "Jew hunts," an activity that quickly became routinized. The reasons this behaviour became entrenched were manifold: some leaders encouraged it; it was a way that soldiers could socialize with each other; there was a certain amount of boredom as soldiers waited and grew listless between battles; antisemitism was more pervasive, and more acceptable; a mentality was growing in which such actions were not only necessary, as part of the war against Jews, who were understood to be intrinsically partisan and Bolshevik, but also justifiable. Beorn does not argue that all soldiers became killers. But he contends that an atmosphere existed in which behaviour (murder of civilians) and planning (genocide) that were supposed to lie outside the scope of military affairs were both pushed and rewarded - "the overall culture in the Wehrmacht was not a neutral one." ${ }^{\prime 9}$ While the reader may have known this before picking up this book, the evidence presented here is both staggering and damning.

Beorn is a careful writer who shows a masterful understanding of the complexities of military organization and decision-making at the lower levels. To a large extent he is able to weave together a narrative about perpetrators that includes their victims as very present figures, using eyewitness accounts and interviews. By virtue of the evidence he has, the perpetrators retain the louder voice, as they do in most books in this field. But faulting a historian for not consulting sources that do not exist is an unfair criticism. Beorn has written an important study about the Holocaust in Belarus, and the involvement of German soldiers in genocide. As such, it is a critical contribution to the fields of Holocaust and perpetrator studies, and is highly recommended for scholars, students, and lay readers interested in these subjects.

${ }^{9}$ Ibid., 228. 